\title{
ELEMENTS OF HISTORICAL NOVEL IN JURJI ZAYDAN'S ISTIBDAD AL-MAMALIK AND NAMIK KEMAL'S JEZMI ${ }^{1}$
}

\author{
By Assoc.Prof.Dr. Bedrettin Aytaç
}

\begin{abstract}
Özet:
19.yy. sonu 20.yy. başını kapsayan dönemde Mısır'da, Suriye ve Lübnan asıllı hıristiyan Arap yazarlarca çok sayıda tarihi roman yazılmıştır. $\mathrm{Bu}$ romanlarla, Arap okuyucusunun dikkatinin tarihe çevrilmesi ve tarih yoluyla bir milli bilinç oluşturulması amaçlanmıştır. Tanzimat dönemini yaşayan Türk edebiyatında da, zor zamanlar geçiren Osmanlı toplumuna, geçmişin büyüklüğünü yansıtmak, tarihten güç almak için tarihi romanlara bir yöneliş olmuştur. Aynı dönemlerde yazılan ve Osmanlı tarihinin farklı dönemlerini konu alan, Corcî Zeydân'ın Ístibdâdu'l-Memâlik ve Namık Kemal'in Cezmi adlı eserleri, tarihi roman unsurları ve vermek istedikleri mesajlar bakımından karşılaştırılabilir özellikler taşımaktadır.
\end{abstract}

In the early periods of the Arab novel, as well as the Turkish one, the historical novels played an important role, and it is worth to mention that both literal pieces had fully adopted the novel tradition of Western literature. In the late 19th and early 20th centuries, a considerable number of historical novels were written in Egypt. These novels had given historical matters more emphasis than literary elements. ${ }^{3}$ It is well known that a majority of those pieces were penned down by Christian Arab intellectuals to provoke the Arab national feelings and to remind the Arab people -- who are not well off at that time, -- of their glorious past. These Syrian-Lebanese origin Christian immigrant intellectuals in Egypt at that time had strong ties with the western world and culture and eager to create an Arab

\footnotetext{
1 This paper was submitted on XXXVI. ICANAS Congress in Montreal, Canada.

2 Ankara University, Faculty of Language, History and Geography Department of Arabic Language and Literature.

${ }^{3}$ see Rahmi Er, Modern Misır Romanı (1914-1944), Ankara 1997, p.56-59.
} 
cultural awakening. ${ }^{4}$ They considered writing historical novels as an important tool to reach their goals. Jurji Zaydan ${ }^{5}$ (1861-1914) and Farah Antun(1874-1922) are worth to mention as pioneers of this literary form in the Egyptian literature. Both writers had choosen the themes of their historical novels from the Islamic history, despite they were not muslim. Jurji Zaydan, who worked as a journalist at the newspapers, al-Zaman and al-Muqtataf in Cairo after he immigrated from Beirut, established his own literary magazine, al-Hilal in 1892. It is remarkable that Jurji Zaydan had chosen the title al-Hilal, in other words "crescent," which is an Islamic symbol, for his literary magazine. Zaydan has also written several books on the Islamic and Arabic history as well as on civilization, but he gained his major fame with his historical novels, influenced by Walter Scott and Alexandre Dumas peré. ${ }^{6}$ These historical novels contributed to the development of the literary Arabic novels also. Similarly, the Turkish literature of the same period witnessed the appearence of historical novels. The novel writers of Tanzimat, also dealt with historical matters to remind the people the brilliant past of the Ottoman Empire which was on the verge of collapse at that time and the magnificent periods of the Islamic history. ${ }^{7}$ Namik Kemal(1840-1888) ${ }^{8}$ and Ahmed Midhat Efendi (1844-1912) are early Turkish historical novel writers. The influence of the historical novels by Walter Scott is quite clear also on the early Turkish historical novels. ${ }^{9}$

${ }^{4}$ see Jacob M. Landau, Modern Arap Edebiyatı Tarihi (20. Yüzyıl) (Çev.Dr.Bedrettin Aytaç), Ankara 1994, p.17,18.

see Carl Brockelmann, Geschichte der Arabischen Literatur, Supplementband, III, E.J.Brill, Leiden 1942, p.186-190.

${ }^{6}$ see J.Brugman, An Introduction to the History of Modern Arabic Literature in Egypt, Leiden 1984, p. 219-222, 226.

7 see Hülya Eraydın Argunşah, Türk Edebiyatında Tarihi Roman (Türk Tarihiyle IIgili), (Doktora Tezi), Marmara Üniversitesi Sosyal Bilimler Enstitüsü, Istanbul 1990, p.14,15.

${ }^{8}$ see Ömer Faruk Akün, "Namık Kemal" Íslam Ansiklopedisi, LX, Milli Eğitim Basımevi, İstanbul 1988, p.54-72.

9 see Hülya Eraydın Argunşah, o.c. p.6; Sadri Ertem, Tarihsel Roman, Roman Anlayıșı (Haz. Baha Dürder), Remzi Kitabevi, İstanbul 1971, p. 120-123. 
Jurji Zaydan's Istibdad al-Mamalik ${ }^{10}$ was one of his 22 historical novels. It is set in Egypt and Syria at the end of the 18th century and was written in 1893 . The novel, which was written by third narrative style, deals with the sufferings and problems of the Egyptian people under the Mamelukes as the Ottoman rule in the area loses grip. The historical data about Egypt in the first chapter of the novel, titled Vikalat al-Sabun, were provided in the light of the abovementioned facts. According to these data, Egypt had been ruled by many Sultans after the Fatimide period, but the worst sufferings of the Egyptian people were experienced after the Mamelukes took over the administration of the country. Following the end of Mameluke rule by the Ottoman Empire, Egypt has been ruled by Pashas who were appointed by Istanbul, Mameluke beys and the military -- the Ojaks. The person in charge of the governorate in Cairo has been called Sheikh al-Balad. The protagonist of the novel, Abd al-Rahman is a merchant who is in a respected position in Cairo's Vikalat al-Sabun quarter. In addition, he is a good and generous person. He is married to Salima and fathers a son named Hasan who receives medical training at that time. Ali Bey al-Kabir, who is Sheikh al-Balad at that time, is a ruthless and greedy administrator, and he is dreaming to be a sovereign power in Egypt with the support of Russia. He collects unfair taxes from his subjects through his loyal servants. In one of such brutal practices, Ali Bey's soldiers arrest the protagonist's wife and son, in false charges that he escaped compulsory military service. Later, Ali Bey al-Kabir orders their execution, but somehow his soldiers feel pity and release the mother and son. As the story approaches to an end, Hasan and Salima manage to arrive in Acre to meet Abd al-Rahman after so much suffering and countless struggles, and the family reunites. At this time Ali Bey's Mameluke army is defeated by the pro-Ottoman forces of Abu al-Zahab Muhammad Bey. Ali Bey is killed in that battle. Following these developments, Abd alRahman goes back to Cairo with his family and they spend the rest of their lives there.

The abovementioned novel, comprises a significant historical structure. The events taking place in the book are supported with

\footnotetext{
${ }^{10}$ see Matti Moussa, The Origins of Modern Arabic Fiction, A Three Continents Book Lynne Rienner Publishers Boulder, London 1997, p. 208,209 .
} 
certain dates. The despotic Mameluke rulers are clearly depicted by alMahruki, a friend of Abd al-Rahman:

"It is weird that they claim to belong to Islam, but Islam can not be associated with either those people or their deeds, which even Pharaohs and Mercusions would not dare. It's true, that the Turkish Pashas have lost their power and the last word is left to the Mamelukes. $"$ "I

The novel informs its readers about the general conditions in Egypt in the late $18^{\text {th }}$ Century as seen here: "At this time the Orthodox Greeks had so many privileges in Egypt, because the Mamelukes were dependent on their skills and knowledge about medicine, silk trade, navigation and shipbuilding ${ }^{\prime \prime 2}$

Also the novel gives us some ideas about the port-city of Alexandria then:

"At that time, Alexandria was a small town. Most importantly, it was on the sea shore, and it had two separate harbors. One of them was located in Ras at-Tin and it was for the use of only Muslims. There anchored only Ottoman and Egyptian boats. The other was for the use of the Christians, and was located in an area called the Old Harbor: ${ }^{1 d .3}$

The Mamelukes' oppressive rule is illustrated as much as possible. As the soldiers take Abd al-Rahman's wife, Salima to a Greek Orthodox church to hide her after deciding not to kill her, they are mistaken by the church staff as plunderers. ${ }^{, 14}$

There is another incident about a conversation between Hasan, Abd al-Rahman's son, and a priest at Saint Ilya monastery in Beirut. The conversation follows as:

"We pray to Allah that may He destroy the administration of the Mamelukes. The history has never before witnessed any more brutal, ruthless and oppressive rulers than them. ${ }^{\text {"IS }}$

\footnotetext{
"Jurji Zaydan, Istibdad al-Mamalik, Dar al-Hilal, p.40.

${ }^{12}$ ibid.p. 78

${ }^{13}$ ibid.p. 109.

${ }^{14}$ see ibid 79 .

${ }^{15}$ ibid.p. 200.
} 
Aside from the history of Egypt, some historical background about Syria is given as well. That can be observed as the novel introduces al-Sheikh Dahir al-Zaydani. ${ }^{16}$

There are also some details of Osman Pasha's efforts to persuade Abu al-Zahab, who recaptured Hejaz from the rebels in order to remain loyal to the Ottoman Sultan in Istanbul. There he says:

"The Queen Of Russia has helped you to overcome the Muslims [in the Balkans] in order to satisfy her goals there. Imagine that you take Hejaz and Syria. What significance does this small piece of territory bear when compared to the much broader Ottoman Empire? How can be the [relatively smaller] armies of Hejaz and Syria be a match for the powerful Ottoman armies which conquered the world with all their courage and strength". ${ }^{17}$

In general, we can comment from this novel that the administration in Istanbul loses control Egypt and there exist proper conditions for the upcoming Napoleonic armies to invade the region.

The characters, like Ali Bey al-Kabir, Osman Pasha, Muhammad Bey Abu al-Zahab, Amir Yusuf al-Shihab, al-Sheikh Dahir al-Zaydani and Russian Admiral Orloff are the real historical personalities. ${ }^{18}$ On the other hand, the novel fictionalizes humanistic qualities like separation, longing and charity. Abd al-Rahman's longing for his wife and son, as well as his reunion with them through the help of the other supporting characters, play an important role in the story's development. Description of the novel characters are very poor and insufficient. Even main character Abd al-Rahman's description is so insufficient. The author did not try to picturize us the inner selves of the characters. That causes a poor fictive structure in the novel. The author positively approaches Abd al-Rahman and Admiral Orloff who supported him, and al-Sheikh Dahir al-Zaydani. We can say that the author does not describe the characters in realistic terms. The characters are depicted as either extremely good or extremely bad personalities.

\footnotetext{
${ }^{16}$ see ibid.p. 115 ,

${ }^{17}$ ibid.p. 162.

18 see Ismail Hakkı Uzunçarşılı, Osmanlı Tarihi, IV, T.T.K. Yayınları, Ankara 1988, p.431,434.
} 
Similarly Namik Kemal, one of the most significant writers and poets of the late Ottoman period, considered literature as a way to provoke nationalist feelings and relay his politically motivated messages. One of his novels presents historical settings for this purpose. The novel, called Jezmi ${ }^{19}$ was written in 1877 , but it takes place in the 16th Century Iran and the Black Sea peninsula of Crimea.

Although, Jezmi himself appears to be the protagonist of the novel; after some reading, we begin to confirm that another character, Adil Giray from Crimea, displays a more eminent feature. Jezmi, when compared to Adil Giray, has a less visible role in that work. In that novel, as in many other historical novels, we observe the failing nations' yearning to return their glorious past. The novelist chose 16th Century as the time setting, most probably because that time period represents the zenith of the Ottoman Empire.

As it is the case for the previous novel, Jezmi also provides its readers with some historical background of the setting. In abstract; Jezmi, originally a poet, willingly takes part in an Ottoman war against Iran, and he heroically serves the army. The Ottoman army helps the allied Crimean forces against the Iranians, and saves Crimean commander Adil Giray from being defeated by his enemies. Later on, the Iranians launch another strike, and the Crimeans and imprison Adil Giray in that second attempt. There begins a love affair involving a trio. Both the Iranian Shah's wife, Shahriyar and his sister Perihan fall in love with Adil Giray at the same time. After the war, Jezmi also goes to Iran volunteering in an attempt to rescue Adil Giray from the Iranians. There the two characters meet for the first time. But tragically, Adil Giray and his lover Perihan are killed by the Iranian guards by the order of Shahriyar at the end of the story.

The novel which was written by third person narrative style, presents us several historical facts: The first of those facts is the war between the Ottoman Empire and Iran which took place in about 1578 , despite the then-Ottoman grand vizier, Mehmed Sokollu was in objection to such a costly military offensive. Secondly, Crimean Khan Mehmed Giray's' brother Adil Giray aligned with the Ottoman empire against the Iranians. In addition, there is a mention of an actual attack

${ }^{19}$ see Sadık Kemal Tural, Tarihi Roman Geleneği veya Cezmi, Doğumunun Yüzellinci Yılında Namık Kemal, Atatürk Kültür, Dil ve Tarih Yüksek Kurumu Yayınları, Ankara 1993, p. 67-91. 

Arapça ve Türkçe Hikmetler

Z1 < Ar. Arap alfabesinin on yedinci harfi: N9a / 17; N17a / 17; N62a / 17.

z1 < Ar. Arap alfabesinin on birinci harfi: N9a / 11; N16b / 11; N61b / 11.

żll < Ar. gölge: $z .-u$ 'llāh "Allah'ın gölgesi" N17a / 17.

zikr < Ar. Allah'ın adlarını söyleyerek anma: N32b / $2 ; \underline{z}+i$ N133a / rubā'i;
N136b / 3; $z+$ in N62a / 27; $\underline{z}+$ in ay- N17a / 23; $\underline{z}+$ in ayta körgil N16b / 9; z. it- N6la / 2.

żiyā < Ar. ışık, aydınlık: N6ıb $/ 15$.

zinhār< Far. sakın: N61b / 11; N135a / 11.

ziyān < Far. zarar: $z+$ dur N16b / 11; N61b / 11. 